\title{
Efektivitas Terapi Kognitif Perilakuan untuk Meningkatkan Efikasi Diri Abstinen NAPZA
}

\author{
Erga Patragave Ratih ${ }^{1} \mathcal{E}$ Muhana Sofiati Utami \\ Fakultas Psikologi Universitas Gadjah Mada
}

\begin{abstract}
The research aimed to determine the effectiveness of Cognitive-Behavior Therapy to increase self efficacy towards multiple drug addicts. The One-Group Pretest-Posttest Design was used in the research. The participants were 6 people who were the resident of Drug Rehabilitation Center "K" located in Sleman, Special Region of Yogyakarta. Pretest and posttest measure by Drug Avoidance Self-Efficacy Scale. Data were analyzed by nonparametric statistics, used Wilcoxon analysis. The results showed significance of 0.0135 . Acording to the results, there was an indication that Cognitive-Behavior Therapy's module was able to increase self efficacy among drug addicts.
\end{abstract}

Keywords: cognitive-behavior therapy; multiple drugs; self efficacy

Abstrak. Penelitian ini bertujuan untuk melihat efektivitas Terapi Kognitif Perilaku untuk meningkatkan efikasi diri pecandu NAPZA. Desain penelitian menggunakan eksperimen kuasi The One-Group Pretest-Posttest Design. Partisipan penelitian ini terdiri dari 6 orang pada kelompok eksperimen yang merupakan residen Pusat Rehabilitasi NAPZA "K" yang berlokasi di Sleman, Daerah Istimewa Yogyakarta. Seluruh partisipan diberikan pretest dan posttest berupa Drug Avoidance Self-Efficacy Scale untuk mengukur perubahan efikasi diri. Hasil analisis statistik non-parametrik menggunakan Wilcoxon menunjukkan signifikansi sebesar 0,0135. Ini artinya hipotesis penelitian ini diterima, yaitu terdapat peningkatan skor efikasi diri pada partisipan setelah diberikan modul Terapi Kognitif Perilakuan.

Kata kunci: efikasi diri; napza; terapi kognitif-perilaku

Penyalahgunaan narkoba merupakan salah satu permasalahan yang saat ini menjadi isu serius di Indonesia. Badan Narkotika Nasional memperkirakan bahwa jumlah pengguna narkoba di Indonesia terus meningkat setiap tahunnya. Data dari Badan Narkotika Nasional mencatat bahwa pada tahun 2015 angka prevalensi penggunaan

\footnotetext{
${ }^{1}$ Korespondensi dapat dilakukan melalui ergapatragave@gmail.com

22Atau melalui sofi_53@ugm.ac.id
}

narkoba berada di kisaran 5,1 juta orang dan kemungkinan besar akan terus meningkat (Fardianto, 2014).

Badan Narkotika Nasional mencatat bahwa sekitar 367.000 orang dengan rentang usia 15 hingga 64 tahun harus merenggang nyawa akibat overdosis yang disebabkan oleh penyalahgunaan narkoba (Silaban, 2014). Kepala Badan Narkotika Nasional Budi Waseso menambahkan bahwa setiap harinya sekitar 40 hingga 50 orang meninggal akibat 
penyalahgunaan narkoba (Santosa, 2016). Selain itu, kerugian negara yang ditimbulkan akibat penyalahgunaan narkoba mencapai Rp.63,1 triliyun (Santosa, 2016).

Di Indonesia jenis narkoba yang paling banyak digunakan adalah jenis Amfetamin, Kanabis dan Ekstasi. Badan Narkotika Nasional pada tahun 2014 memperkirakan bahwa jumlah ganja yang digunakan sebanyak 158 juta gram ganja (Desideria, 2014). Data dan fakta yang cukup memperihatinkan tersebut kemudian menjadi salah satu pertimbangan pemerintah untuk menyatakan bahwa Indonesia mengalami darurat narkoba (Sihaloho, 2017).

Tidak hanya di Indonesia, penyalahgunaan narkoba juga menjadi isu global di berbagai negara. UNODC merupakan salah satu badan organisasi Perserikatan Bangsa Bangsa (PBB) yang memiliki fokus dalam narkotika dan kriminal mencatat bahwa di dunia terdapat sekitar 246 juta orang yang menyalahgunakan narkoba atau prevalensinya sebesar 5,2 persen dari total jumlah penduduk dunia (United Nation Office on Drugs and Crime, 2016). Jenis narkoba yang paling banyak digunakan adalah Kanabis dengan total 232 ribu orang dan Amfetamin dengan total 53 ribu orang (United Nation Office on Drugs and Crime, 2016).

Pemerintah telah melakukan berbagai macam usaha untuk menekan angka penyalahgunaan narkoba di Indonesia, mulai dari usaha preventif hingga kuratif. Di Indonesia tindak pidana narkotika telah diatur dalam Undang-Undang no 35 tahun 2009 (Undang-Undang Negara no 35, 2009). Salah satu upaya preventif yang saat ini gencar dilakukan pemerintah untuk menekan angka penyalahgunaan narkoba adalah dengan menghentikan alur peredaran narkoba, yaitu memberikan ancaman hukuman mati bagi siapapun yang terbukti memperjual-belikan dan menyeludupkan narkoba (Hermawan, 2015). Armandani (2014) menyampaikan bahwa untuk menekan penyalahgunaan narkoba tidak bisa dilakukan hanya dengan menangkap para bandar saja, tetapi juga melalui terapi atau rehabilitasi bagi para pecandu narkoba.

Salah satu usaha kuratif yang dilakukan oleh pemerintah untuk menyembuhkan ketergantungan seseorang terhadap narkoba adalah dengan melakukan rehabilitasi. Pemerintah dalam UndangUndang no 35 tahun 2009 pasal 54 menjelaskan bahwa pecandu atau pengguna narkoba wajib untuk menjalani rehabilitasi baik yang bersifat medis dan sosial untuk melepaskan mereka dari jeratan narkoba (Badan Narkotika Nasional, 2013a). Sebagai upaya untuk melepaskan pecandu narkoba dari jeratan narkoba, pemerintah telah gencar melakukan rehabilitasi bagi pengguna narkoba dan mendirikan berbagai pusat rehabilitasi yang tersebar di berbagai wilayah Indonesia (Badan Narkotika Nasional, 2103a). Pada tahun 2015 Badan Narkotika Nasional bersama dengan presiden Republik Indonesia dan kementerian terkait telah merehabilitasi sebanyak 100 ribu orang penyalahguna narkoba dalam program yang diberi nama Gerakan Rehabilitasi 100 Ribu Penyalahguna Narkoba (Anggiawan, 2015).

Metode rehabilitasi yang gencar dilakukan oleh pemerintah nampaknya dapat dikatakan belum mencapai hasil yang maksimal, karena masih tingginya angka kekambuhan atau relapse pada para mantan pecandu narkoba. Badan Narkotika Nasional mencatat bahwa sekitar hampir 90 persen mantan pecandu narkoba yang menjalani proses rehabilitasi, mengalami kekambuhan dan kembali menyalahgunakan narkoba (Badan Narkotika Nasional, 2013b). Data dari Badan Narkotika Nasional menunjukkan bahwa sekitar 6000 orang pecandu yang mengikuti program rehabilitasi, 40 persennya kembali mengalami kekambuhan (Andrisias, 2013).

Amalia (2016) dalam penelitiannya di Lembaga Rehabilitasi Napza KUNCI di Daerah Istimewa Yogyakarta menemukan 
bahwa semenjak tahun 2011 terdapat residenresiden yang mengalami kekambuhan setiap tahunnya. Prianto (2007) dalam penelitiannya di pusat rehabilitasi berbasis komuniti PSPP "Sehat Mandiri" Kalasan, Daerah Istimewa Yogyakarta, menemukan bahwa hanya sekitar 26,46 persen pecandu napza yang telah pulih dan kembali ke pada keluarganya sejak tahun 2014.

Tidak hanya di Indonesia, permasalahan kekambuhan atau relapse juga menghantui para mantan pecandu narkoba di negara lain. Maarevfand et al. (2015) dalam penelitiannya di pusat-pusat rehabilitasi narkoba di Iran menemukan angka yang cukup signifikan yaitu sekitar 75 persen hingga 95 persen para mantan pecandu narkoba mengalami kekambuhan dan kembali mengkonsumsi narkoba. Habil (2001) dalam penelitiannya juga menemukan bahwa lebih dari 70 persen mantan penyalahguna narkoba yang mengikuti rehabilitasi mengalami kekambuhan. Merchant (2002) dalam penelitiannya menemukan bahwa orang-orang yang mengikuti program Therapeutic Community, memiliki kerentanan untuk mengalami kekambuhan beberapa bulan setelah mereka menyelesaikan program, dikarenakan adanya tekanan psikologis dan sosial.

Ibrahim dan Kumar (2009) dalam penelitiannya menemukan ada tiga faktor penting yang berperan dalam munculnya kekambuhan. Pertama adalah rendahnya efikasi diri, yang kemudian menjadikan individu mudah merasa putus asa dan mudah menyerah dalam menghadapi tantangan hidup. Kedua adalah kurangnya dukungan sosial dari lingkungan sekitar atau komunitas sekitar, karena komunitas kurang bisa menerima kembali mantan pecandu napza. Ketiga adalah kurangnya dukungan sosial dari anggota keluarga, karena adanya komunikasi yang kurang efektif dan disfungsional di dalam keluarga. Penelitian tentang faktor-faktor yang berkontribusi terhadap relaps dengan menggunakan kuisioner, juga menemukan bahwa keyakinan kepada diri sendiri dan kepercayaan diri memegang peranan penting dalam proses kekambuhan dengan kontribusi sebesar 62,4 persen (Lian dan Chu, 2013; Ibrahim, Samah, Talib, \& Sabran, 2009). Faktor lain yang juga berperan dalam proses kekambuhan adalah dukungan sosial dengan kontribusi sebesar 2,2 persen dan dukungan keluarga dengan kontribusi sebesar 0,7 persen.

Berdasarkan penjabaran di atas terlihat bahwa efikasi diri memegang peranan yang penting dalam munculnya kekambuhan. Secara umum Marlatt dan Gordon (1985) mendefinisikan efikasi diri sebagai sebuah proses kognitif, yang melibatkan penilaian seseorang terhadap kemampuan dirinya, yang kemudian akan mempengaruhi perilaku serta hasil. Efikasi diri bersifat spesifik terhadap suatu situasi tertentu dan bukan bersifat umum seperti halnya kepercayaan diri. Bandura (1977) mendefinisikan efikasi diri sebagai sebuah rasa berdaya, rasa mampu dan kemampuan individu untuk berperilaku sesuai dengan situasi serta kondisi tertentu. Peranan efikasi diri dalam kehidupan seharihari sangat penting, karena efikasi diri dapat menentukan bagaimana individu akan berperilaku ke depannya.

Lebih spesifik DiClemente, Prochaska dan Gibertini (1985) menyatakan bahwa salah satu spesifikasi efikasi diri yang paling sering diukur dan diteliti pada kasus perilaku adiktif adalah efikasi diri abstinen. Efikasi diri abstinen memiliki kontribusi yang besar dalam memicu munculnya perilaku adiktif kembali atau kekambuhan. DiClemente (1986) mendefinisikan efikasi diri abstinen sebagai keyakinan diri individu terhadap kemampuannya untuk tetap abstinen dari perilaku adiktif, apabila berada dalam situasi dan kondisi yang dapat memicu munculnya kembali perilaku adiksi.

Berdasarkan definisi di atas mengenai efikasi diri, dapat digaris bawahi bahwa efikasi diri merupakan sebuah proses kognitif dan penguasaan kemampuan spesifik yang 
membentuk pandangan dan keyakinan seseorang terhadap kemampuan dirinya sendiri dalam melakukan perilaku tertentu yang bersifat spesifik. Efikasi diri yang tinggi, memungkinkan seseorang melakukan suatu perilaku dengan keyakinan diri yang tinggi pula, begitupun sebaliknya (Bandura, 1977; Marlatt \& Gordon, 1985). Dari sini dapat disimpulkan bahwa proses kognitif dan penguasaan kemampuan spesifik memainkan peranan penting dalam pembentukan efikasi diri individu. Ini menandakan bahwa efikasi diri dapat dimaksimalkan melalui programprogram dan terapi-terapi yang menekankan pada proses kognitif dan latihan pembentukkan perilaku.

Larimer, Marlatt dan Palmer (1999) secara spesifik menjelaskan bahwa meningkatkan efikasi diri abstinen, penting agar individu dapat mempertahankan perilaku abstinennya dengan penuh keyakinan dan tidak mudah menyerah ketika berhadapan dengan situasi beresiko menggunakan napza. Oleh karena itu penting untuk memberikan individu terapi yang berisi latihan perilaku koping dan kemampuan berpikir positif.

Terapi Kognitif Perilakuan atau CBT merupakan salah satu terapi yang tepat untuk mengatasi permasalahan terkait efikasi diri, karena telah didukung oleh berbagai bukti ilmiah. Penelitian yang dilakukan oleh Kumar dan Sebastian (2011) menunjukkan bahwa CBT memiliki dampak yang positif dalam meningkatkan efikasi diri siswa dalam meraih prestasi akademik sekolah. Bardideh, Bardideh, \& Kakabaraee (2017) dalam penelitiannya menemukan bahwa teknik CBT memiliki dampak yang sangat signifikan dalam meningkatkan efikasi diri pada anakanak penderita kanker, yang kemudian dalam kaitannya untuk mengurangi rasa sakit.

Penelitian lain yang dilakukan pada para penderita penyakit kronis menunjukkan bahwa terjadi peningkatan efikasi diri secara signifikan, setelah para partisipan diberikan terapi dengan menggunakan teknik CBT
(Nash et al, 2013). Saedi, Hatami, Parviz, Ahadi, \& Poursharifi (2016) dalam penelitiannya juga menemukan bahwa para pasien penderita penyakit kronis yang diberikan terapi CBT, meningkat efikasi dirinya dan kemudian dapat mengurangi rasa sakit dari proses pengobatan yang mereka jalani.

Hipotesis penelitian ini adalah terapi kognitif perilakuan mampu secara efektif meningkatkan efikasi diri abstinen napza residen pusat rehabilitasi napza berbasis komunitas.

\section{Metode}

Variabel independen dalam penelitian ini yaitu Terapi Kognitif Perilakuan. Definisi operasional Terapi Kognitif Perilakuan adalah terapi yang bertujuan untuk rekstrukturisasi kognitif, pengelolaan emosi dan latihan perilaku melalui psikoedukasi, thought catching, relaksasi, reality testing, interoceptive exposure, afirmasi dan role play. Variabel dependen dalam penelitian ini adalah efikasi diri abstinen. Efikasi diri abstinen adalah proses kognitif yang melibatkan penilaian seseorang terhadap kemampuan diri dan keyakinan diri untuk dapat bertahan dalam perilaku abstinen, sebagaimana diukur dengan Drug Abstinent Self-Efficacy Scale (Martin et al., 1995) yang telah diadaptasi oleh Efditianur (2018).

Partisipan penelitian terdiri dari 6 orang yang dipilih secara tidak acak, menggunakan metode purposive sampling berdasarkan kriteria/ inklusi yang telah ditetapkan peneliti. Seluruh partisipan merupakan residen Pusat Rehabilitasi NAPZA “K” Sleman, DIY.

Penelitian ini menggunakan metode penelitian kuantitatif dengan jenis penelitian eksperimen kuasi. Desain penelitian eksperimen kuasi menggunakan The OneGroup Pretest-Posttest Design yang meneliti satu variabel independen dengan satu kelompok terikat pengukuran pra-perlakuan 
dan pasca-perlakuan. (Shadish, Cook \& Campbell, 2002).

Pengukuran pra-perlakuan dan pascaperlakuan menggunakan Drug Abstinen SelfEfficacy Scale yang telah diterjemahkan dan dimodifikasi ke dalam bahasa indonesia untuk mengukur efikasi diri (Efditianur, 2018; Martin et al, 1995).

Pengujian hipotesis dilakukan dengan menggunakan pendekatan statistik nonparametrik (Distribution free statistics) berupa uji Wilcoxon, untuk melihat perbedaan skor pra-perlakuan dan pasca-perlakuan dalam sebuah kelompok. Selain itu, dilakukan juga analisis deskriptif yang diperoleh melalui lembar pegangan partisipan, lembar evaluasi terapi, lembar hasil observasi dan cheklist Terapi Kognitif Perilakuan.

\section{Hasil}

Pada Tabel 1 tercantum skor mentah efikasi diri seluruh partisipan yang diperoleh melalui pengukuran pra-perlakuan dan pengukuran pasca-perlakuan.

Tabel 1.

Skor Mentah Efikasi Diri Pra-Perlakuan dan Pasca-Perlakuan

\begin{tabular}{lll}
\hline Inisial & $\begin{array}{l}\text { Pra- } \\
\text { Perlakuan }\end{array}$ & $\begin{array}{l}\text { Pasca- } \\
\text { Perlakuan }\end{array}$ \\
\hline AR & 53 & 76 \\
\hline EI & 61 & 80 \\
\hline TBS & 88 & 96 \\
\hline JA & 53 & 76 \\
\hline SP & 70 & 83 \\
\hline AN & 79 & 80 \\
\hline
\end{tabular}

Berdasarkan Tabel 1 terlihat bahwa seluruh partisipan yang termasuk dalam kelompok eksperimen, mengalami peningkatan skor efikasi diri setelah diberikan intervensi berupa Terapi Kognitif Perilakuan. Selain itu, terdapat peningkatan skor rerata sebelum diberikan perlakuan dan setelah diberikan perlakuan. Nilai rerata pada skor pra-perlakuan adalah sebesar 70,67 dan nilai rerata pada skor pasca-perlakuan meningkat menjadi 83,50. Kemudian untuk memastikan apakah perubahan ini secara statistik signifikan, maka dilakukan uji hipotesis menggunakan uji Wilcoxon.

Tabel 2 menunjukkan bahwa seluruh partisipan memiliki selisih ranking negatif sebesar 0 dan selisih ranking positif sebesar 6 . Jumlah ranking positif sebesar 21,00 dan jumlah Ranking negatif sebesar 0,00. Dikarenakan ranking negatif memiliki skor lebih rendah dibandingkan ranking positif $(0,00<21,00)$, ini artinya $\mathrm{T}$ hitung memiliki nilai sebesar 0,00 . $T$ hitung pada penelitian ini memiliki skor yang lebih rendah daripada $\mathrm{T}$ tabel Wlicoxon satu arah $(0,00<2)$. Selain itu, diperoleh skor signifikansi sebesar 0,0135 yang mana lebih kecil daripada 0,025 (Sig. $0,0135<0,025)$. Ini artinya dapat disimpulkan bahwa hipotesis penelitian ini diterima, yaitu Terapi Kognitif Perilakuan efektif dalam meningkatkan efikasi diri abstinen napza.

\section{Diskusi}

Hasil uji beda satu arah dengan menggunakan Wilcoxon menunjukkan bahwa terdapat perbedaan yang signifikan dengan skor signifikansi sebesar 0,0135. Ini artinya hipotesis penelitian ini diterima, Terapi Kognitif Perilakuan efektif meningkatkan efikasi diri abstinen napza. Adanya peningkatan skor efikasi diri seluruh partisipan, menandakan bahwa sesi mengenali perasaan, penangkapan pikiran, relaksasi, testing realitas, afirmasi, interoceptive exposure dan role play mampu untuk meningkatkan efikasi diri individu.

Seluruh partisipan mampu mengidentifikasi perasaan dan pikiran negatif yang muncul pada situasi beresiko, yang seringkali memicu mereka berperilaku menggunakan napza. Kesuksesan partisipan untuk melakukan sesi penangkapan perasaan, penangkapan pikiran negatif dan identifikasi situasi beresiko inilah yang kemudian menjadi salah satu pilar pendukung 
keberhasilan proses terapi ini. Larimer, Marlatt \& Palmer (1999) menyebutkan bahwa dengan membantu individu untuk mampu melakukan identifikasi terhadap situasi

Tabel 2.

Tabel Ranking

\begin{tabular}{lllll}
\hline & & N & Rerata Ranking & Jumlah Ranking \\
\hline Posttest- & Ranking Negatif & 0 & 0,00 & 0,00 \\
Pretest & Ranking Positif & 6 & 3,50 & 21,00 \\
& Seri & 0 & & \\
\hline & Total & 6 & & \\
\hline
\end{tabular}

beresiko menggunakan napza dan membantu mereka untuk sadar terhadap perasaan dan pikiran otomatis yang muncul pada situasi tersebut, merupakan salah satu langkah untuk menjadikan keyakinan diri individu meningkat dan mencegah individu kembali ke dalam kekambuhan. Selain itu Bandura (1977) menjelaskan bahwa salah satu dari empat sumber yang mempengaruhi tinggirendahnya efikasi diri adalah penguasaan kemampuan. Melalui latihan penangkapan pikiran, penangkapan perasaan dan identifikasi situasi berisiko partisipan diberikan penguasaan kemampuan yang efektif untuk meningkatkan efikasi dirinya.

Setelah melakukan sesi testing realitas dengan cara menguji keyakinan negatif yang mereka miliki, seluruh partisipan menjadi yakin bahwa pikiran negatif/disfungsional yang selama ini mereka yakini adalah tidak benar. Seluruh partisipan juga mampu menemukan alternatif pikiran lain yang lebih rasional untuk mengganti pikiran negatif tersebut. Kesuksesan partisipan untuk mampu menguji keyakinan negatif dan menggantikan keyakinan tersebut dengan pikiran yang lebih rasional, yang kemudian menjadi salah satu poin pendukung keberhasilan terapi ini. Larimer, Marlatt dan Palmer (1999) menyebutkan bahwa dalam upaya untuk membantu individu meningkatkan keyakinan diri dan terhidar dari kekambuhan, dapat dilakukan dengan cara memberikan strategi koping yang efektif, bentuk strategi koping dapat berupa perilaku dan kognitif, salah satu bentuk koping kognitif yang dapat diberikan adalah rekonstruksi kognitif. Bandura (1977) menyebutkan salah satu dari empat sumber yang mempengaruhi tinggi rendahnya efikasi diri adalah penguasaan kemampuan. Melalui testing realitas, partisipan diberikan penguasan kemampuan koping yang efektif, untuk meningkatkan efikasi dirinya.

Hampir seluruh partisipan mampu melakukan sesi afirmasi dengan baik dan lancar, kecuali partisipan AN. Partisipan yang berhasil melakukan teknik afirmasi, mampu menemukan kalimat-kalimat positif, motivasional dan membangun untuk diucapkan kepada diri mereka sendiri. Partisipan yang berhasil melakukan teknik afirmasi merasa bahwa teknik ini bermaanfaat untuk membantu mereka lebih berpikir positif terhadap diri sendiri dan menjadikan perasaan mereka lebih banyak dipenuhi oleh emosi-emosi positif.

Keberhasilan hampir semua partisipan melakukan teknik afirmasi menjadi salah satu pilar penting yang mendukung keberhasilan terapi ini. Larimer, Marlatt dan Palmer (1999) mengatakan bahwa strategi koping yang efektif seperti self talk atau afirmasi, dapat membantu individu untuk menghadapi situasi beresiko menggunakan napza dan meningkatkan keyakinan dirinya. Bandura (1977) menjelaskan bahwa salah satu dari sumber yang menentukan tinggi-rendahnya efikasi diri adalah penguasaan kemampuan, melalui teknik afirmasi partisipan diberikan penguasaan kemampuan koping yang efektif untuk meningkatkan efikasi dirinya. 
Seluruh partisipan mampu melakukan sesi interceptive exposure dengan sukses dan lancar. Seluruh partisipan mampu membayangkan situasi yang tidak menyenangkan/ situasi beresiko, merasakan sensasi fisik dan emosi yang muncul. Partisipan kemudian mampu melakukan afirmasi dan relaksasi untuk membantu mereka menenangkan pikiran, kondisi fisik dan emosi mereka. Kesuksesan seluruh partisipan melakukan sesi interoceptive exposure menjadi salah satu pilar utama yang menjadikan terapi ini berhasil. Larimer, Marlatt dan Palmer (1999) menjelaskan bahwa keyakinan diri individu akan meningkat apabila dirinya memiliki strategi koping yang efektif dan merasa yakin akan kemampuan diri ketika berhadapan dengan situasi beresiko menggunakan napza. Interoceptive exposure terbukti sukses membantu seluruh partisipan untuk merasa yakin terhadap diri mereka sendiri, ketika dihadapkan dengan situasi beresiko. Bandura (1977) menjelaskan bahwa salah satu dari empat sumber yang mempengaruhi tinggi-rendahnya efikasi diri individu adalah kondisi emosi dan fisiologis. Melalui teknik interoceptive exposure, partisipan dilatih untuk mampu mengendalikan kondisi fisik dan emosinya agar lebih stabil dan meningkatkan efikasi dirinya.

Seluruh partisipan mampu melakukan latihan komunikasi efektif dan asetif dengan lancar. Partisipan terlihat sangat antusias ketika bermain peran dan terlihat sangat menikmati peran yang mereka mainkan. Kesuksesan seluruh partisipan melakukan latihan komunikasi efektif dan asertif melalui role play, menjadi salah satu pilar yang mendukung tercapainya keberhasilan terapi ini. Seperti yang telah disampaikan oleh Larimer, Marlatt dan Palmer (1999) yaitu salah satu strategi untuk meningkatkan keyakinan diri individu dan menurunkan resiko kekambuhan, dapat dilakukan dengan memberikan individu latihan berupa komunikasi efektif dan asertif. Bandura (1977) menjelaskan bahwa salah satu dari empat sumber yang mempengaruhi tinggirendahnya efikasi diri adalah penguasaan kemampuan. Melalui teknik role play partisipan telah mampu memiliki penguasaan kemampuan komunikasi efektif dan asertif untuk meningkatkan efikasi dirinya.

Seluruh partisipan kecuali partisipan AN, merasakan manfaat yang cukup besar dari teknik relaksasi yang diberikan. Partisipan yang mampu melakukan relaksasi dengan sukses, merasakan bahwa relaksasi mampu menjadikan tubuh mereka lebih nyaman, emosi mereka lebih stabil dan pikiran mereka lebih tenang. Kesuksesan hampir seluruh partisipan melakukan teknik relaksasi, menjadi salah satu pilar penting yang mendukung keberhasilan terapi ini. Seperti yang telah disampaikan oleh Larimer, Marlatt dan Palmer (1999) bahwa teknikteknik seperti relaksasi, meditasi atau yoga mampu menjadikan emosi, fisik dan pikiran individu lebih tenang, sehingga menjadikan mereka mampu berpikir dan bertindak dengan lebih tepat apabila berhadapan dengan situasi beresiko menggunakan napza. Keberhasilan individu mengahadapi situasi beresiko dengan tepat, maka akan meningkatkan keyakinan diri dan menurunkan potensi kekambuhan.

Pada checklist Terapi Kognitif Perilakuan, kelima perserta tercatat mampu mencapai tujuan dari masing-masing sesi terapi. Akan tetapi pada AN, dirinya tercatat belum mampu untuk mencapai tujuan pada sesi relaksasi dan sesi afrimasi. Selain itu melalui hasil wawancara, diketahui bahwa AN seringkali masih menyalahkan orang lain seperti ayahnya, istrinya dan keluarganya atas apa yang menimpa dirinya saat ini. AN masih belum bisa menerima sepenuhnya bahwa dirinya salah, meskipun demikian ia menyadari bahwa rehabilitasi merupakan cara untuk membantu dirinya lepas dari jerat penyalahgunaan napza.

DiClemente et al., (1985) menyatakan bahwa terdapat beberapa tahapan perubahan 
yang dilalui oleh individu, ketika dirinya sedang menjalani masa pemulihan dari zat. Salah satunya adalah tahapan kontemplasi, pada tahapan ini individu menyadari bahwa dirinya memiliki masalah akan tetapi individu masih belum sepenuhnya memiliki komitmen untuk bergerak. Kemungkinan besar pada saat ini AN masih berada dalam tahapan kontemplasi, di mana AN menyadari bahwa dirinya memiliki masalah ketergantungan zat, akan tetapi dirinya belum sepenuhnya memiliki komitmen untuk bergerak.

\section{Kesimpulan}

Terapi Kognitif Perilakuan efektif meningkatkan efikasi diri abstinen napza yang menjalani rehabilitasi napza di pusat rehabilitasi berbasis komunitas. Dengan meningkatnya efikasi diri abstinen partisipan, diharapkan partisipan akan mampu untuk terhindar dari kekambuhan.

Saran

Tidak adanya kelompok kontrol dalam penelitian ini menjadi salah satu kelemahan. Peneliti selanjutnya yang ingin melakukan replikasi, diharapkan menggunakan desain eksperimen dengan kelompok kontrol.

Salah satu partisipan berinisial JA, memiliki dual diagnosis selain ketergantungan zat, yaitu halusinasi auditori. Dalam rangka menghindari adanya variabel pencemar, peneliti lain yang ingin melakukan replikasi dapat melakukan kontrol terhadap diagnosis.

Seluruh partisipan dalam penelitian ini berjenis kelamin laki-laki. Peneliti lain yang ingin melakukan replikasi diharapkan dapat melakukan penelitian kepada partisipan berjenis kelamin perempuan.

\section{Daftar Pustaka}

$\begin{array}{ccc}\text { Amalia, } \mathrm{N} . \quad(2016) . & \begin{array}{c}\text { Efektivitas } \\ \text { rehabilitasi }\end{array} & \begin{array}{r}\text { program } \\ \text { korban }\end{array} \\ \text { penyalahgunaan } & \text { NAPZA } & \text { melalui }\end{array}$

pendekatan therapeutic community oleh lembaga kunci Nandan. (Skripsi tidak dipublikasikan). Yogyakarta: Universitas Gadjah Mada.

Andrisias, S. W. (2013). Stigma negatif menjadi faktor utara mantan pecandu relapse. Diunduh dari http://www.kabarindonesia.com/berit a print.php?id=20130626155856

Anggiawan, F. (2015). 2015, BNN canangkan gerakan rehabilitasi 100 ribu pecandu. Retrieved from https://news.okezone.com/read/2015/0 3/19/337/1121

115/2015-bnn-canangkan-gerakanrehabilitasi-100-ribu-pecandu

Armandani, K. (2014). Begini terapi bagi pecandu narkoba. Retrieved from

https://www.cnnindonesia.com/nasio nal/20140829122141-12-2038/beginiterapi-bagi-pecandu-narkoba/

Badan Narkotika Nasional. (2013a). Penanganan korban penyalahguna narkoba oleh BNN. Diunduh dari http://www.bnn.go.id/read/artikel/103 69/penanganan-korbanpenyalahguna-narkoba-oleh-bnn

Badan Narkotika Nasional. (2013b). Keluarga miliki peran vital dukung penyalahguna narkoba. Diunduh dari http://www.bnn.go.id/read/berita/114 30/blog-single.html

Bandura, A. (1977). Self-efficacy: Toward a unifying theory of behavioral change. Psychological Review, 84(2), 191-215.

Bardideh, K., Bardideh, F \& Kakabaraee, K. (2017). Study of the efficacy of cognitive behavioral group treatment on anger rumination and resilience of cardiovascular patients. Global Journal of Health Science, 9(4), 163-173. doi: 10.5539/gjhs.v9n4p163

DiClemente, C., Prochaska, O. J \& Gilbertini, M. (1985). Self-efficacy and the stages of self-change of smoking. Cognitive Therapy and Research, 9(2), 181-200. 
Desideria, B. (2014). Tiga jenis narkoba ini paling banyak digunakan. Diunduh dari http://health.liputan6.com/read/ 2263693/tiga-jenis-narkoba-ini-palingbanyak-digunakan

DiClemente, C. (1986). Self efficacy and addictive behavior. Journal of Social and Clinical Psychology, 4(3), 302-315. doi: 10.1521/jscp.1986.4.3.302

Efditianur, D. (2018). Peran koping terhadap lamanya masa abstinence penyalahguna narkotika dengan mediator efikasi diri dan perceived social support. (Tesis tidak dipublikasikan). Yogyakarta: Universitas Gadjah Mada.

Fardianto, F. (2014). Pengguna narkoba di Indonesia pada 2015 capai 5,8 juta jiwa. Diunduh dari https://www.merdeka.com/peristiwa/ pengguna-narkoba-di-indonesiapada-2015-capai-58-juta-jiwa.html

Habil, H. (2001). Managing heroin addicts through medical therapy. Kuala Lumpur: University Malaya Press.

Hermawan, B. (2015). BNN: hukuman mati bagi bandar narkoba sesuai undang-undang. Diunduh dari www.republika.co.id/berita/nasional/ hukum/15/01/19/nie1uh-bnnhukuman-mati-bagi-bandar-narkobasesuai-undangundang

Ibrahim, F \& Kumar, N. (2009). Factors effecting drug relapse in Malaysia: An empirical evidence. Asian Social Scienes Journal, 5(12), 37-44. doi: $10.5539 /$ ass.v5n12p37

Ibrahim, F., Samah, B. A., Talib, M. A \& Sabran, M. S. (2009). Faktor menyumbang kepada penagihan relaps dalam kalangan penagih dadah PUSPEN di Semenanjung Malaysia. Jurnal Antidadah Malaysia, 5, 235-251.

Larimer, E. M., Palmer, S. R \& Marlatt, G. A. (1999). Relapse prevention, an overview of marlatt's cognitivebehavioral model. Alcohol Research $\mathcal{E}$ Health, 23(2), 151-160.
Lian, C. T \& Chu, Y. F. (2013). A qualitative study on drug abuse relapse in Malaysia: Contributory factors and treatment. International Journal of Collaborative Research on Internal Medicine E Public Health, 5(4), 217-232.

Maarevand, M., Eghlima, M., Rafiey, H., Rahgozar, M., Deilamizadeh, A., Ekhtiari, H \& Tadayyon, N. (2015). Community-based relapse prevention for opiate dependents: A randomized community controlled trial. Community Mental Health Journal, 51, 21-29. doi: 10.1007/s10597014-9772-1

Marlatt, G. A. \& Gordon, J. R. (1985). Relapse prevention: Maintenance strategies in the treatment of addictive behaviors. New York: Guilford Press.

Martin, W. G., Wilkinson, D. A \& Poulos, X. C. (1995). The drug avoidance selfefficacy scale. Journal of Substance Abuse, 7(2), 151- 163.

Mendoza, Z. (2008). Efektivitas terapi kognitif perilaku terhadap pasien yang mendapatkan pengobatan anti ansietas. (Tesis tidak dipublikasikan). Yogyakarta: Universitas Gadjah Mada.

Mendoza, Z., Rahmasari, R., Retnowati, S., Risnawati \& Sasmitawati, T. A. (2008). Terapi kognitif perilaku. Modul Terapi Universitas Gadjah Mada. Yogyakarta: Universitas Gadjah Mada

Merchant, C. R. (2002). Substance abuse, personality disorders, and comorbid disorders among parolees and probationers. (Disertasi tidak dipublikasikan). Howard: Howard University.

Nash, V., Ponto, J., Townsend, C., Nelson, P \& Bretz, M. (2013). Cognitive behavioral therapy, self-efficacy, and depression in persons with chronic pain. Pain Management Nursing, 14(4), 236-243. doi: 10.1016/j.pmn.2012.02.006

Prianto, P. H. (2007). Penerapan pendekatan therapeutic community terhadap korban 
penyalahgunaan napza di PSPP "Sehat Mandiri" Yogyakarta. (Tesis tidak dipublikasikan). Yogyakarta: Universitas Gadjah Mada.

Saedi, S., Hatami, M., Parviz, A., Ahadi, H \& Poursharifi, H. (2016). The effectiveness of cognitive-behavioral therapy on alexithymia and pain selfefficacy of patients with chronic pain. International Journal of Medical Research $\mathcal{E}$ Health Sciences, 50(11), 277-284.

Santosa. (2016). BNN : 50 orang meninggal per hari karena narkoba. Diunduh dari http://www.antaranews.com/berita/548 440/bnn--50-orang-meninggal-per-harikarena-narkoba

Shadish, W. R., Cook, T. D., \& Campbell, D. T. (2002). Experimental and quasi experimental designs for generalized causal inference. NewYork: Houghton Mifflin
Sihaloho, J. M. (2017). Indonesia sudah darurat narkoba, ini faktanya. Diunduh dari http://www.beritasatu.com/nasional/4 22437-indonesia-sudah-daruratnarkoba-ini-faktanya.html

Silaban, W. M. (2014). 200 juta orang meninggal akibat narkoba per tahun. Diunduh dari https://nasional.tempo.co/read/588287 200-juta-orang-meninggal-akibatnarkoba-per-tahun\#LgyxdrwkV22i

United Nation Office on Drugs and Crime (2016). Responses to annual report questionnaire. Diunduh dari http://www.unodc.org/wdr2016/. 